\author{
A.V. Drygval ${ }^{1 *}$, P.V. Drygval ${ }^{2}$, R.V. Gorbunov ${ }^{1}$, V.A. Lapchenko ${ }^{3}$ \\ ${ }^{1}$ A.O. Kovalevsky Institute of Biology of the Southern Seas of RAS, Sevastopol, Russia; \\ ${ }^{2}$ Peoples' Friendship University of Russia (RUDN University), Moscow, Russia; \\ ${ }^{3}$ T.I. Vyazemsky Karadag Scientific Station - Nature Reserve of RAS - \\ Branch of A.O. Kovalevsky Institute of Biology of the Southern Seas of RAS, Feodosia, Kurortnoye, Russia \\ *Corresponding author: drygval95@mail.ru
}

\title{
Functioning of steppe landscapes in the autumn season by the example of the Karadag Nature Reserve
}

\begin{abstract}
The results of the functioning of low-mountain sub-Mediterranean steppe landscapes in the autumn period (from 2014 to 2019) are obtained on the example of the Karadag Nature Reserve. The results of the processes of "development", "destruction" of both prerequisites and results of landscape functioning and "accumulation" of prerequisites for landscape development, as well as mixed categories in the autumn season are distinguished. Relatively alternating with each other, in the autumn season, the process of accumulation of prerequisites (in 2015, 2016, and 2019) and the process of development (in 2014 and 2017, respectively) have minimum values. In 2018, the processes of accumulation and development are at the same level, and each account for $2.6 \%$ of the total number of the processes observations, which occurred in the steppe landscapes this year. The autumn season is absolutely dominated by the process of destruction of prerequisites and results of functioning in landscapes. This process varies from $93.9 \%$ in 2014 to $98.8 \%$ in 2016 .
\end{abstract}

Keywords: functioning of steppe landscapes, types of states, weather types, meteorological parameters, autumn season, Karadag Nature Reserve, Crimean Peninsula.

\section{Introduction}

Landscape dynamics are inextricably linked to its functioning and are seen as a sequence or more complex structure of landscape transition from one state to another. Changes of states and maintenance of landscape in one state are provided by different functional processes [1]. Therefore, the study of the dynamics of any landscape system is based precisely on the study of functional processes which take place in them.

The processes that manifest themselves in the landscape and the study of its dynamics, are characterized by a rhythmic manifestation. They can be active at relatively equal intervals of time and lead to changes in the state of individual components of the landscape throughout the year [2].

Our article deals with intraday states of landscapes associated with measurements of system parameters every hour. Intraday dynamic is determined by such external environmental factors, which are caused by the influence of the sun, and have a rapid change (within a few minutes), as they differ only in parameters associated with the transformation of solar energy [1].

The stable sequence of changing landscape states is defined as the temporal structure of the landscape [3]. In many studies, as in ours, landscape dynamics is studied precisely through the change of its states [4-9].

In the study of landscape dynamics, stationary studies are of great importance. For example, Beruchashvili N.L. has developed a functional model of the landscape at the Martkop stationary on the basis of the substance and energy flows in the landscape system [7]. The Roztocze landscapes also quantify indicators of substance and energy flows by determining the main parameters of radiation, water, and heat balances [10]. Geochemical and geophysical features of landscapes are studied at the Chernogorsk station, in their strategies, synergetic and spatial, and temporal organization, as well as regime landscape-monitoring observations (meteorological, hydrological and phenological) [11-13]. Krauklis A.A. had been carrying out studies in the Priangar taiga facies since 1963. He conducted long-term observations of the natural regimes of typical southern taiga facies in the Chunoyarsk station. He paid special attention to the study of seasonal cycles and regeneration-age dynamics of dark taiga [14-16].

Also phenological research methods are now actively used as an approach to the study of landscape dynamics. In central Russia, phenological data is collected by the Moscow branch of the Russian Geographical Society (RGS). In the northwestern region, this has been carried out for a long time by the staff of the Botanical Institute of the Russian Academy of Sciences. In the Far East, long-term phenological monitoring is conducted at the Orotuk stationary of the IBPS FEB RAS (Kolyma River headwater). In addition, phenologi- 
cal studies are carried out in the phenological section of the Sverdlovsk Branch of the Russian Geographical Society at the Ural Pedagogical University by a group of students and followers of Batmanov V.A.: Yantser O.V., Terentyeva E.Yu., Skok N.V., and others [17].

At present, the study of years-long states of landscapes that characterize their functioning remains as an urgent task. Knowledge of the mechanisms of interaction between landscapes and their environmental conditions makes it possible to solve problems of predicting their dynamic patterns and trends [18].

The methodology, taken as the basis of our study of the landscape dynamics' states, was developed by Mamay I.I. [4] when studying the functioning of landscapes at the Lesunovo landscape stationary [19-22].

\section{Experimental}

The approach used in this paper is the landscape functional assessment approach according to the methodology [4]. Based on the completeness of the primary data for assessing the dynamics of landscape states, a specific approach to the assessment was chosen: level;

1) The rank of the territorial complex is selected: at the facies, natural landmark (tract) or landscape

2) The rank of periodic states observations of the territorial complex is selected: intraday, diurnal, intraseasonal, seasonal, intra-annual, and multi-annual states.

In this work, the functioning of the natural system is given at the landscape level. Intraday meteorological indicators of the Karadag station of baseline environmental monitoring (fixing meteorological data every hour), as well as materials of the "Annals of Nature" [23-28], where indicators were applied for some of the diagnostic attributes of landscape functioning, were used as source data.

The diagnostic signs for assessing the functioning of steppe landscapes in the autumn season are those processes, which manifest themselves within steppe landscapes and which can be assessed over the time period. For over 6 years (2014-2019) we assessed the following diagnostic attributes, which are proposed in the methodology [4]. The diagnostic signs include:

- Heat transfer;

- Moisture transfer;

- Wind speed;

- Precipitation;

- Phytomass growth, vegetation;

- Increase of moisture in soil;

- Freezing and thawing of soil;

- Surface sediments transfer;

- Change of soils of one type by another while preserving the type of soil formation;

- The emergence of new morphological parts of the landscape or the disappearance of old ones;

- State of vegetation, phenology;

- Soil formation;

- Evaporation and transpiration;

- Surface runoff;

- Change of ground water level.

Each of these diagnostic signs refers to a particular category of functioning results, which influence the development of steppe landscapes as a whole. The results of landscape functioning include "development", "accumulation" of prerequisites and "destruction" of prerequisites and results of landscape functioning.

A certain type of weather conditions establishes the result of steppe landscape functioning: development, accumulation and destruction of different degrees of intensity (weak, medium, strong). In one type of weather conditions all named results or only some of them can be realized simultaneously. When assessing each process, among the results of the functioning of landscapes are defined:

- Strong development (3 scores);

- Medium development (2 scores);

- Weak development (1 score);

- Strong accumulation (3 scores);

- Medium accumulation (2 scores);

- Weak accumulation (1 score);

- Stabilization (0 score); 
- Weak destruction (1 score);

- Medium destruction (2 scores);

- Strong destruction (3 scores).

Scores can reflect both positive "+" and negative "--", as well as the contribution of each diagnostic signs to the overall result of landscape functioning. Correspondingly, scores with a "+" and "-" signs reflect the strengthening or weakening of these functional signs in the landscape.

The autumn season is characterized by different categories of results of steppe landscape functioning with different degrees of intensity of their manifestation. The final results of steppe landscape functioning in the autumn season include development, destruction of both prerequisites and results of steppe landscape functioning, and accumulation of prerequisites for landscape development, as well as mixed categories.

Study Area

The Karadag Nature Reserve is located on the shore of the Black Sea, between the Otuzka River valley and the Koktebel hollow. The climate of this area is characterized as hot, arid, with mild winters, and the area is classified as the south-eastern climatic region of Crimea. In general, the territory of the reserve is insufficiently wetted. $87 \%$ of annual precipitation evaporates and only $13 \%$ (53 mm) forms surface runoff [29].

\section{Results}

The duration of the autumn season in 2014-2019 varies greatly from 60 to 108 days. Autumn occurs between 24 September (2014) and 23 October (2018). The end of autumn is marked between 13 December (2016) and 13 January (2017). The longest autumn was recorded in 2017 with 108 days, while the shortest autumn season was in 2016 with 60 days.

In the autumn period of 2019, it was impossible to assess the situation under which the functioning of steppe landscapes took place. As for technical reasons there were difficulties in obtaining meteorological data from the Karadag station of baseline environmental monitoring in the period from 13 November to 27 November (on these days there is no data on the amount of precipitation, so it was not possible to identify weather types. Therefore, this period was not taken for the functioning assessment).

The autumn season from 2014 to 2019 is characterized by 48 types of weather in the study area. In 2014, 35 types occur, in 2015 - 27 types, in 2016 - 34 types, in 2017 and 2018 - 30 types, and in 2019 26 types were identified (given the lack of weather data for some period of the autumn season in 2019). Some weather types recur during each year and some occur only in certain years of the studied time period.

One of the results of the steppe landscapes functioning in autumn is the landscape "development" process. This was observed throughout the entire six-year time period. A weak development process was present in all the listed years, however, also in the period from 2014 to 2017, weather types were noted in which the development process was classified as a medium category, and strong development was noted in all years except 2015.

During the autumn period, based on methodology [4], such diagnostic signs as surface sediments transfer, change of soils of one type by another while preserving the type of soil formation, the emergence of new morphological parts of the landscape or the disappearance of old ones, state of vegetation, phenology, soil formation are classified as developmental.

The result of steppe landscape functioning, such as the "accumulation" of prerequisites for landscape functioning was noted in the autumn periods of 2014, 2016, 2017, and 2018. Moreover, it was pointed out that the category of strong accumulation is completely absent in the autumn season. The processes of prerequisites accumulation in the autumn season according to the methodology [4] include diagnostic signs: heat transfer, moisture transfer, wind regime, precipitation, phytomass growth and vegetation, increase of moisture in soil.

The process of "destruction" of both prerequisites and results of landscape functioning is characteristic for the whole period under consideration, with all categories of intensity (weak, medium and strong result of functioning) occurring in each year. Among the signs influencing the overall destruction result in the autumn season according to the methodology [4], the following are highlighted: heat transfer, moisture transfer, wind regime, evaporation and transpiration, and surface runoff.

The following categories of outcomes are related to the manifestation of two, three or more parallel steppe landscape processes or combinations thereof. In this case, the intensity of the manifestation of the result is zero and it is characterized by the definition "in the absence of result". This suggests that the parallel processes in the type of weather under consideration have levelled each other, resulting in the same level of their functioning, i.e. the intensity of the processes does not stand out. 


\section{Discussion}

During the autumn season each of the diagnostic signs contributed to the overall picture of steppe landscape functioning.

Development of steppe landscapes. The process of development in different years was caused by different diagnostic signs, but it was mainly dominated by the surface sediments transfer, which is inseparably linked with the intensity of precipitation in this season. Besides, such signs as the emergence of new morphological parts of the landscape or the disappearance of old ones in the period under consideration and the change of soils of one type by another were not manifested, while preserving the type of soil formation.

The percentage of cases (of the total number of observations) of the result with weak development varies from $0.1 \%$ to $3.4 \%$. Generally, this category of landscape functioning is a fraction of a percent and does not exceed $0.6 \%$ of the total number of process observations. In 2019, however, this category accounted for $3.4 \%$. This category is mainly characterized by diagnostic signs such as the surface sediments transfer and soil formation.

In 2016, 2018, and 2019, such a diagnostic sign as "state of vegetation and phenology" affected the overall picture of steppe landscape functioning and levelled out the overall positive result of the functioning of weak development. This sign makes the most of its negative contribution in 2019. In 2014 and 2015, it had no influence at all on the overall steppe landscape functioning result.

Medium landscape's development in the autumn season is supported by the surface sediments transfer and soil formation. The other diagnostic signs do not have the intensity for which the current category of steppe landscape functioning results. It is important to note that in 2018 and 2019 no weather types with a landscape functioning result such as medium development were identified. This category of functioning result is poorly represented among the others and amounts to no more than $0.5 \%$ of the total number of observations. Overall, average development as a result of steppe landscape functioning occurs in fractions of a percentage of the total number of observations: $0.1 \%$ in 2014 and 2015, $0.3 \%$ in 2016, and $0.5 \%$ in 2017.

The functioning result characterized as a strong development was considered in all years except for 2015. The dominant diagnostic sign is the surface sediments transfer, which makes the main contribution to the category of strong development. Parallel to this, soil formation makes a positive contribution to this category too. There is also a negative impact of the diagnostic attribute "state of vegetation and phenology" on the final result of this category in 2019. During the autumn season, this diagnostic sign actively influences the reduction of the category result through the weakening and complete termination of flowering processes.

The percentage of the total number of observations with a strong development result varies from $0.1 \%$ in 2014, 2017, and 2018 to no more than $0.4 \%$ in 2016. The development process itself accounts for small fractions of a percentage of the autumn season compared to other processes.

Accumulation of prerequisites for the steppe landscapes functioning. The accumulation of prerequisites for the steppe landscapes functioning is weak and not all diagnostic signs are presented in this category. Such sign as wind regime does not appear at all in this category of results. Also, it is presented the negative impact of "phytomass growth and vegetation" on the general process of accumulation, indicating that this sign increasing the weakness of overall result of weak accumulation functioning in autumn 2016 and 2018. Observations (of the total number) with weak accumulation of prerequisites for steppe landscape functioning constitute a very small percentage: $0.1 \%$ in 2016 and $1.2 \%$ in 2018 .

The next category of the result intensity of steppe landscapes functioning is the medium accumulation. It occured only in 2014 and 2017 and was realized through wind activity, precipitation, phytomass growth and vegetation, moisture transfer, and increase of moisture in the soil. In addition, wind speed affected this category of functioning only in 2014 and moisture transfer only in 2017. A negative contribution in 2014 and 2017 to the overall steppe landscape functioning result in this category is brought by the sign "phytomass growth and vegetation", as the autumn season tends to depress phytomass growth in plant communities. The percentage of the average accumulation result from the total number of observations is $0.1 \%$ in 2014 and $0.7 \%$ in 2017.

Destruction of prerequisites and results for steppe landscape functioning. Weak destruction of results is not implemented by all diagnostic signs in this category of landscape functioning. For example, surface runoff is not a diagnostic sign in none of the years under consideration, the activity of which would influence the overall result of weak destruction. Individual attributes do not reflect their contribution in the autumn season functioning of some years (for example, the wind regime does not have such activity in 2015 to influence the total result of the considered category of steppe landscapes functioning). 
Autumn 2017 was characterized by the smallest number of diagnostic signs actively acting on the described result; only three diagnostic signs standed out in this year: heat transfer, wind speed, change of groundwater level.

It should be noted that changes in the groundwater level in 2014 and 2015 contributed positively to the overall process of destruction of the results, while in 2017 and 2018 it contributed negatively, with a strong intensity. Due to this, the destruction of the steppe landscape in the autumn of 2017 and 2018 was weakened.

The percentage of cases (of the total number of observations) with weak destruction of steppe landscape results varies from $0.4 \%$ to $8.4 \%$. The lowest values are characteristic of 2014,2015 , and $2019(1.51 \%$, $0.4 \%$ and $2.1 \%$, respectively). In 2016 it is $8.4 \%$, in $2017-6.9 \%$ and in $2018-4.6 \%$ of the total number of observations.

In the medium destruction of result of steppe landscapes functioning, all diagnostic signs were active, except for surface runoff. This diagnostic signs did not manifest itself at all in those types of weather, when the category of medium destruction of results operated. There was a negative impact of the sign "change of groundwater level" on the total contribution to the result of this category of functioning in 2014-2019.

This category of steppe landscape functioning varies between $0.8-28.2 \%$ of the total number of observations. Between 2014 and 2018, this percentage ranged from $0.8 \%$ to $6.9 \%$, and increased sharply in 2019 $(28.2 \%)$.

The result of the landscape functioning as a strong destruction of the results is manifested under more types of weather. Thus, heat transfer in the air, moisture transfer, wind regime, evaporation and transpiration and change of groundwater level are active in the autumn season in all years under consideration. Little activity of surface runoff was recognized in autumn 2016, where it made a small positive contribution to the overall result of functioning of steppe landscapes.

As in the other categories of intensity of result, destruction in the last three years (2017-2019) had a negative contribution of the diagnostic sign "change of groundwater level". In these years, there was a frequent increase in the groundwater level during the autumn season. This category of performance result varies between $57.6 \%$ and $89.6 \%$ of the total number of observations. The minimum percentage of observations that characterize the functioning result of this category is noted in $2019(57.6 \%)$. Between 2014 and 2018, this percentage remained approximately at the same level, ranging from $82.5 \%$ to $89.6 \%$ (the maximum was noted in 2015).

The result of steppe landscape functioning as a destruction of prerequisites was only noted in 2015 and 2018.

The medium destruction of prerequisites is typical for some weather types only in 2018. The more intense category of strong destruction of preconditions was found in 2015. These functioning processes add up to different diagnostic signs. Only three diagnostic signs contributed in both 2015 and 2018. Such signs include: wind regime, evaporation and transpiration, and change of groundwater level. Moreover, the negative impact of the signs on the general result was made by different processes: in 2018, with medium destruction of the prerequisites the negative contribution to the overall result of landscape functioning was made by change of groundwater level, while in 2015, with a strong destruction of the prerequisites the negative contribution to the total result was made by evaporation and transpiration.

The percentage of cases (of the total number of observations) with medium destruction of steppe landscape prerequisites in the autumn season 2018 is $3.8 \%$, and with strong destruction of prerequisites in 2015 is $0.8 \%$.

An interesting category of performance is the one in which both prerequisites and results destruction processes occur together. Such categories of different intensities were observed throughout the whole period under consideration, except for 2016. It must be said that evaporation and transpiration are presented in almost all years and at all intensity categories of the functioning results, except for 2019, in which the medium intensity category is absent. However, in the autumn of 2015 with weak intensity of this result category evaporation and transpiration made a negative contribution to the total functioning result of steppe landscapes. This diagnostic sign is joined by others. Each year a particular range of diagnostic signs dominated. There is an absolute lack of activity of diagnostic signs in 2019 with a weak category of intensity of the process. This suggests that within each diagnostic sign that manifested itself in a particular weather type in 2019, there was a mutual balancing of positive and negative scores affecting the overall result with zero process manifestation result. It is noted that in the autumn season of 2019 with the category of strong intensity of the considered result of functioning only one diagnostic sign was manifested - it is wind speed. 
The category of steppe landscape functioning, such as weak destruction of preconditions and results has the following percentage distribution of the total number of observations: $0.2 \%$ in $2015,1.3 \%$ in 2018 and $0.3 \%$ in 2019 . The medium category has the following distribution: $1 \%$ in $2014,0.6 \%$ in 2015 and $1.9 \%$ in 2016. In 2016 and 2019, this result at a strong level is $1.3 \%$ and $7.1 \%$, respectively.

Co-dominant categories of steppe landscape functioning. When assessing the joint accumulation and development category of steppe landscape functioning, it is noted that it occured in all years except autumn 2018. Among the fundamental diagnostic signs there are: wind regime, precipitation, phytomass growth and vegetation, increase of moisture in soil, surface sediments transfer, state of vegetation and phenology, soil formation. Additionally, considering all years, two diagnostic signs contributed negatively to the overall results of this category during the autumn season. These are phytomass growth and vegetation, and also vegetation condition and phenology, which are due to the fact that in the autumn season active processes of vegetation flowering and growth cease and are inhibited, so a stronger negative impact of these attributes is found in deep autumn near winter.

The accumulation and development category accounts for small fractions of a percentage of the total number of observations. The years 2014, 2016, 2017, and 2019 accounted for just $0.1 \%$ and 2016 for $0.2 \%$ of the results in this category.

The next result with parallel processes of landscape functioning is the development and destruction of the result. This result category occurs in the autumn season in all years. It should be noted that the diagnostic signs influencing the overall result in each year is soil formation. It is joined by other diagnostic signs with different levels of contribution in different years. There is a negative contribution of some signs in 2014, 2015, 2017 and 2018. These include: state of vegetation and phenology, as well as change of groundwater level (only in autumn 2018).

In general, the occurrence of this category varies between $0.1-1.9 \%$ of the total number of observations. In 2014, 2016 and 2017, there is the lowest percentage of occurrence of this steppe landscape result among all observations, $0.3 \%, 0.3 \%$ and $0.1 \%$ respectively, while in 2015, 2018 and 2019 the occurrence increases to $1.9 \%, 1.1 \%$ and $0.9 \%$, respectively.

A significant contribution to the functioning of the steppe landscapes of individual years in the autumn season is made by the category of accumulation and destruction of prerequisites. This category of steppe landscape functioning is evident in autumn in 2014 and 2017. In these years, almost all characteristic diagnostic signs are observed, with a high level of negative contribution of phytomass and vegetation growth, as well as change of groundwater level (only in 2017). The occurrence of this category result does not at all exhibit heat transfer as a process of destruction. The occurrence of this category of steppe landscape functioning result is $9.6 \%$ in 2014 and $2.4 \%$ in 2019 (\% of total observations per season).

The last category of the result of the steppe landscapes functioning in autumn is the category which includes all the processes: accumulation, development and destruction, running in parallel. However, only some of the diagnostic attributes appear in this category and influence its result. Among them: heat transfer (as accumulation), moisture transfer (as accumulation), wind regime (as accumulation), precipitation, phytomass growth and vegetation, increase of moisture in soil, surface sediments transfer, state of vegetation and phenology, soil formation, moisture transpofer (as destruction), evaporation and transpiration, surface runoff, change of groundwater level.

This mixed category of steppe landscape results is found in all years of the time period, except for the autumn season of 2016. It is noted that in 2018, the intensity of such diagnostic signs as phytomass growth and vegetation, as well as state of vegetation and phenology contribute more negatively to this category of functioning than in other years. On the contrary, such diagnostic signs as moisture transfer, accumulation make the largest positive contribution compared to other years.

Comprehensively, various signs have a negative impact on the overall steppe landscape functioning in individual years, including: phytomass growth and vegetation, state of vegetation and phenology, evaporation and transpiration, precipitation and change of groundwater level. This category of steppe landscape functioning accounts for small percentages of occurrence: in 2014, 2015, 2017, and 2019, it is only up to $0.2 \%$, and in $2018-4 \%$ of the total number of observations.

\section{Conclusions}

In general, the autumn season in the period of 2014-2019 is characterized by the presence of both accumulation and development and destruction processes, together with the parallel processes of various steppe landscape functioning. 
By grouping and summarizing the main categories of steppe landscape functioning processes in the autumn season, a graph of their correlation and dynamics in the time period under consideration was obtained. The graph (Fig. 1) illustrates that in the autumn season, the process of destruction in steppe landscapes absolutely dominates. It ranges from $93.9 \%$ in 2014 to $98.8 \%$ in 2016 (of the total number of functioning processes within the study area). In turn, the processes of development and accumulation are weak and do not exceed a total of $5 \%$, in some years they characterized by fractions of percentages of the total picture of functioning of steppe landscapes.

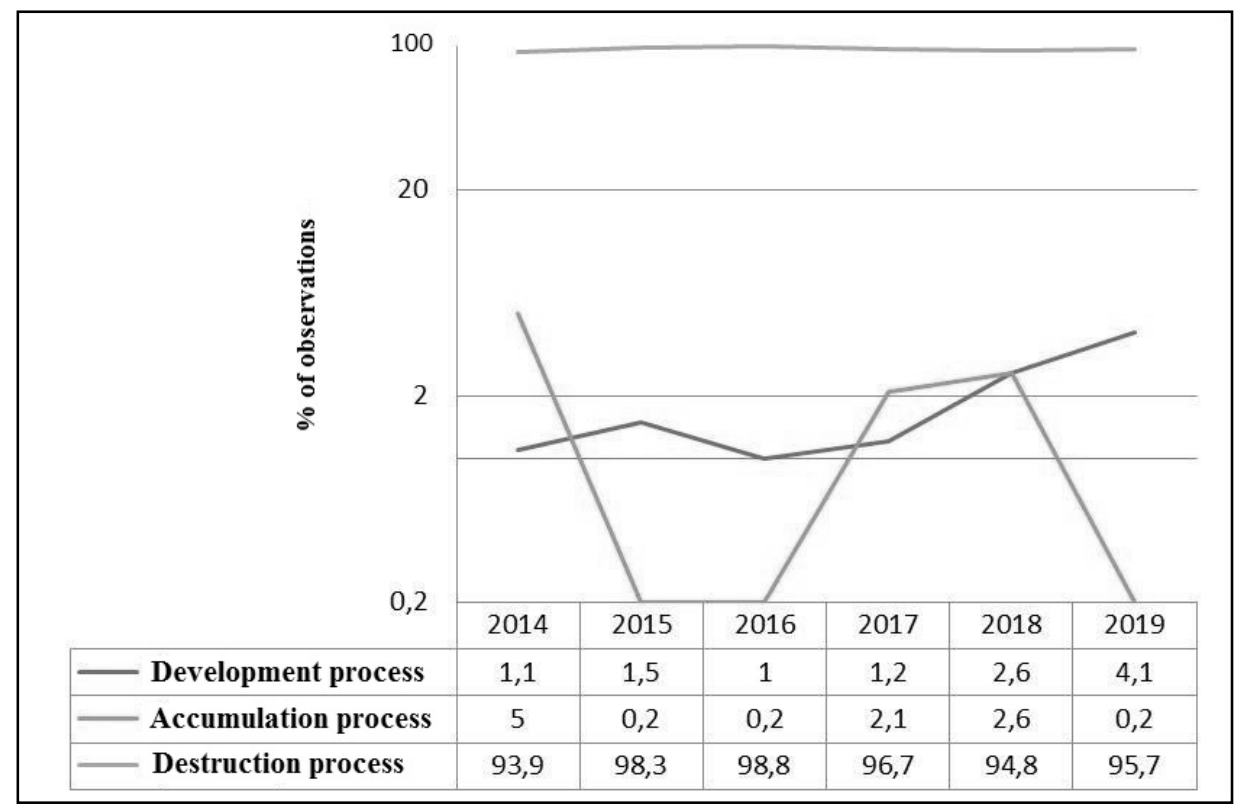

Figure 1. Processes functioning in steppe landscapes in the autumn season, their correlation and dynamics in the period 2014-2019

Figure 1 shows that relatively alternating with each other, in the autumn season in different years, the accumulation process of prerequisites for functioning and the development process in steppe landscapes are characterized by minimal values. The accumulation process makes the minimum contribution among the other processes in 2015, 2016, and 2019, and the development process is in 2014 and 2017, respectively. In 2018 the processes of accumulation and development are at the same level and make up $2.6 \%$ from the processes occurring in the steppe landscapes in the autumn season of this year.

\section{Acknowledgements}

The study was made as a part of the IBSS researches (registration numbers: 121040100327-3 and 121032300023-7). This paper has been supported by the RUDN University Strategic Academic Leadership Program.

\section{References}

1 Гродзинський М.Д. Ландшафтна екологія / М.Д. Гродзинський. - Киев: Знання, 2014. — 550 с.

2 Токарев А.А. Геохимический подход в изучении ритмики морфологических единиц ландшафта / А.А. Токарев, В.А. Шальнев // Наука. Инновации. Технологии. - 2017. - № 1. - С. 163-174.

3 Исаченко А.Г. География сегодня / А.Г. Исаченко. — М.: Просвещение, 1979. — 192 с.

4 Мамай И.И. Динамика ландшафтов. (Методика изучения) / И.И. Мамай. — М.: Изд-во МГУ, 1992. — 167 с.

5 Беручашвили Н.Л. Понятие «состояние геосистемы» в географии / Н.Л. Беручашвили // Вопросы изучения состояний окружающей среды. - 1982. - С. 10-21.

6 Беручашвили Н.Л. Вопросы классификации состояний природно-территориальных комплексов / Н.Л. Беручашвили // Вопросы географии. Ландшафтоведение: теория и практика. — 1982. — Сб. 121. — С. 73-80.

7 Беручашвили Н.Л. Четыре измерения ландшафта / Н.Л. Беручашвили. — М.: Мысль, 1986. — 182 с. 
8 Беручашвили Н.Л. Этология ландшафта и картографирование состояний природной среды / Н.Л. Беручашвили. Тбилиси: ТГУ, 1989. - 196 с.

9 Беручашвили Н.Л. Геофизика ландшафта / Н.Л. Беручашвили. — М.: Высш. шк., 1990. — 287 с.

10 Муха Б.П. Розтоцький ландшафтно-геофізичнийстаціонар: формування, розвиток, науковінадбання / Б.П. Муха. Львов: Видавничий центр ЛНУ ім. Івана Франка, 2010. - 126 с.

11 Миллер Г.П. Исследования динамики и развития ПТК полустационарными и экспедиционными методами / Г.П. Миллер, В.Н. Петлин. — Львов: Вид-во Львівськ. унів., 1985. — 69 с.

12 Петлін В.М. Стратегія ландшафту / В.М. Петлін. — Львов: Видавничий центр ЛНУ ім. Івана Франка, 2007. — 288 с.

13 Чорногірский географічнийстаціонар (навчальнийпосібник) / під ред. І.М. Волошина. - Львов: Вид-во Львівськ. унів., 2003. - 132 с.

14 Южная тайга Приангарья: Структура и природные режимы южнотаежного ландшафта: сб. ст. / АН СССР. Сиб. отд. Ин-т географии Сибири и Дальнего Востока; отв. ред. В.Б. Сочава. — Л.: Наука, 1969. — 267 с.

15 Топологические аспекты учения о геосистемах: сб. / АН СССР. Сиб. отд. Ин-т географии Сибири и Дальнего Востока; отв. ред. В.Б. Сочава. - Новосибирск: Наука, 1974. — 290 с.

16 Природные режимы и топогеосистемы Приангарской тайги: сб. ст. / АН СССР. Сиб. отд. Ин-т географии Сибири и Дальнего Востока; отв. ред. А.А. Крауклис. - Новосибирск: Наука, 1975. — 279 с.

17 Синельникова Н.В. Сезонная жизнь природы Верхней Колымы / Н.В. Синельникова, М.Н. Пахомова. - М.: Товарищество научных изданий КМК, 2015. - 329 с.

18 Хромых В.С. Некоторые теоретические вопросы изучения динамики ландшафтов / В.С. Хромых // Вестн. Томск. гос. ун-та. — 2007. — № 298. - С. 198-207.

19 Мамай И.И. Ландшафтный стационар в Мещере / И.И. Мамай // География и природные ресурсы. — 2003. — № 2. — C. $63-66$.

20 Мамай И.И. О вкладе зимних состояний природных территориальных комплексов в их развитие / И.И. Мамай // Изв. Рус. геогр. общ-ва. — 2007. - Т.139, № 4. - С. 18-29.

21 Мамай И.И. О вкладе весенних состояний природных территориальных комплексов в их развитие / И.И. Мамай // Изв. Рус. геогр. общ-ва. — 2008. — Т. 140. - С. 9-20.

22 Мамай И.И. Закономерности развития природных территориальных комплексов в летние сезоны (на примере ЮгоВосточной Мещеры) / И.И. Мамай // Изв. рус. геогр. общ-ва. — 2010. — Т. 142, № 1. - С. 21-31.

23 Летопись природы. Т. ХХХІ. 2014 г. - Карадаг, 2015. - 197 с.

24 Летопись природы. Т. XXXII. 2015 г. - Карадаг, 2016. - 189 с.

25 Летопись природы. Т. XXXIII. 2016 г. - Карадаг, 2017 - 198 с.

26 Летопись природы. Т. XXXIV. 2017 г. - Карадаг, 2018 - 239 с.

27 Летопись природы. Т. XXXV. 2018 г. - Карадаг, 2019. - 235 с.

28 Летопись природы. Т. XXXVI. 2019 г. - Карадаг, 2020.

29 Костенко Н.С. Климат / Н.С. Костенко, О.В. Кукушкин, А.В. Зуев // Карадаг заповедный: науч.-попул. очерки. Симферополь: Н. Оріанда, 2011. - С. 29-39.

\author{
А.В. Дрыгваль, П.В. Дрыгваль, Р.В. Горбунов, В.А. Лапченко
}

\title{
Карадаг табиғи қорығының мысалында күзгі маусымда дала ландшафттарының жұмыс істеуі
}

\begin{abstract}
Карадаг табиғи қорығының мысалында күзгі кезеңдегі (2014 жылдан 2019 жылға дейін) төментаулы Жерорта теңізінің дала ландшафттарының жұмыс істеу нәтижелері алынды. Осындай нәтижелер негізінде күзгі маусымда мынадай процестер анықталды: ландшафттардың жұмыс істеу нәтижелерінің алғышарттарының «дамуы», «жойылуы» және ландшафттардың дамуы үшін алғышарттардың «жинақталуы», сондай-ақ аралас санаттар. Бір-бірімен салыстырмалы түрде ауысып, күзгі маусымда жұмыс істеу алғышарттарын жинақтау процесі (2015, 2016 және 2019 жылдары), содан кейін даму процесі (сәйкесінше 2014 және 2017 жылдары) ең аз мәнге ие. 2018 жылы жинақтау және даму процестері бір деңгейде болып табылады және биылғы жылы дала ландшафттарында болып жатқан процестерді бақылаудың жалпы санының 2,6 \%-ын құрайды. Күзгі маусымда ландшафттардың жұмыс істеуінің алғышарттары мен нәтижелерін жою процесі мүлдем басым болған. Ол 2014 жылдан 93,9 \%-дан 2016 жылға дейін 98,8 \%-ға дейін ауытқыған.
\end{abstract}

Кілт сөздер: дала ландшафттарының жұмыс істеуі, түрлердің жағдайы, ауа-райының түрлері, метеорологиялық параметрлер, күз мезгілі, Карадаг табиғи қорығы, Қырым түбегі. 


\title{
А.В. Дрыгваль, П.В. Дрыгваль, Р.В. Горбунов, В.А. Лапченко \\ Функционирование степных ландшафтов в осенний сезон на примере Карадагского природного заповедника
}

\begin{abstract}
На примере Карадагского заповедника получены результаты функционирования низкогорных субсредиземноморских степных ландшафтов в осенний период (с 2014 по 2019 гг.). В качестве таких результатов в осенний сезон выделяются процессы: «развитие», «уничтожение» как предпосылок, так и результатов функционирования ландшафтов и «накопление» предпосылок для развития ландшафтов, а также смешанные категории. Относительно чередуясь между собой, в осенний сезон минимальными значениями обладает то процесс накопления предпосылок функционирования (в 2015, 2016 и 2019 гг.), то процесс развития (соответственно в 2014 и 2017 гг.). В 2018 г. процессы накопления и развития находятся на одном уровне и составляют по 2,6 \% от общего количества наблюдений за процессами, происходящими в степных ландшафтах в этом году. В осенний сезон абсолютно преобладает процесс уничтожения предпосылок и результатов функционирования ландшафтов. Он варьирует в пределах от 93,9 \% в 2014 г. до 98,8 \% в 2016 г.
\end{abstract}

Ключевые слова: функционирование степных ландшафтов, типы состояний, типы погоды, метеорологические параметры, осенний сезон, Карадагский природный заповедник, Крымский полуостров.

\section{References}

1 Grodzinskiy, M.D. (2014). Landshaftna ekologiia [Landscape ecology]. Kiev: Znannya [in Ukrainian].

2 Tokarev, A.A., \& Shalnev, V.A. (2017). Geokhimicheskii podkhod v izuchenii ritmiki morfologicheskikh edinits landshafta [Geochemical approach in studying the rhythmics of landscape morphological units]. Nauka. Innovatsii. Tekhnologii - Science. Innovations. Technologies, 1, 163-174 [in Russian].

3 Isachenko, A.G. (1979). Geografiia segodnia [Geography today]. Moscow: Prosveshchenie [in Russian].

4 Mamay, I.I. (1992). Dinamika landshaftov. (Metodika izucheniia) [Landscape dynamics: (Study methodology)]. Moscow: MSU Publ. [in Russian].

5 Beruchashvili, N.L. (1982). Poniatie «sostoianie geosistemy» v geografii [The concept of "geosystem state" in geography]. Voprosy izucheniia sostoianii okruzhaiushchei sredy - Questions for state of environmental study, 10-21 [in Russian].

6 Beruchashvili, N.L. (1982). Voprosy klassifikatsii sostoianii prirodno-territorialnykh kompleksov [Issues of natural-territorial complexes states' classification]. Voprosy geografii. Landshaftovedenie: teoriia i praktika - Geography questions. Landscape study: theory and practice, 121, 73-80 [in Russian].

7 Beruchashvili, N.L. (1986). Chetyre izmereniia landshafta [The four dimensions of landscape]. Moscow: Mysl [in Russian].

8 Beruchashvili, N.L. (1989). Etologiia landshafta i kartografirovanie sostoianii prirodnoi sredy [Landscape ethology and mapping of natural environment states]. Tbilisi: TSU [in Russian].

9 Beruchashvili, N.L. (1990). Geofizika landshafta [Geophysics of the landscape]. Moscow: Vysshaia shkola [in Russian].

10 Mukha, B.P. (2010). Roztotskii landshaftno-geofizichniy statsionar: formuvannya, rozvitok, naukovinadbannya [Roztocze Landscape Geophysical Station: Formation. development. scientific activities]. Lvov: Publishing Center of the Ivan Franko National University of Ukraine [in Ukrainian].

11 Miller, G.P., \& Petlin, V.N. (1985). Issledovaniia dinamiki i razvitiia PTK polustatsionarnymi i ekspeditsionnymi metodami [Studies of the dynamics and development of PTK by semi-stationary and expeditionary methods]. Lviv: Lviv State University [in Russian].

12 Petlin, V.M. (2007). Strategiia landshaftu [Landscape strategy]. Lviv: Vidavnichij centr LNU im. Ivana Franka Publ. [in Ukrainian].

13 Chornogirskii geografichnij statsionar (navchal'nij posibnik) [Chernogrskiy geographical station (textbook)] (2003). Voloshin I.M., Ed., Lviv, Lviv State University Publ. [in Ukrainian].

14 (1969). Yuzhnaia taiga Priangaria: Struktura i prirodnye rezhimy yuzhnotaezhnogo landshafta: sbornik statei [Southern taiga of the Angara region: Structure and natural regimes of the southern taiga landscape: a collection of articles]. USSR Academy of Sciences. Siberian Branch. Institute of Geography of Siberia and the Far East; ed. B. Sochava. Novosibirsk: Nauka [in Russian].

15 Sochava, B. (Ed.) (1974). Topologicheskie aspekty ucheniia o geosistemakh: sbornik [Topological aspects of geosystems doctrine: collection]. USSR Academy of Sciences. Siberian Branch. Institute of Geography of Siberia and the Far East; Novosibirsk: Nauka [in Russian].

16 (1975). Prirodnye rezhimy i topogeosistemy Priangarskoi taigi: sbornik statei [Natural regimes and topogeosystems of the Angara taiga: collection of articles]. USSR Academy of Sciences. Siberian Branch. Institute of Geography of Siberia and the Far East. Novosibirsk: Nauka [in Russian].

17 Sinelnikova, N.V., \& Pakhomov, M.N. (2015). Sezonnaia zhizn prirody Verkhnei Kolymy [Seasonal life of nature in Upper Kolyma]. Moscow: Tovarishchestvo nauchnykh izdanii KMK [in Russian]. 
18 Khromykh, V.S. (2007). Nekotorye teoreticheskie voprosy izucheniia dinamiki landshaftov [Some Theoretical Issues in the Study of Landscape Dynamics] Vestnik Tomskogo gosudarstvennogo universiteta - Bulletin of the Tomsk State University, 298, 198-207 [in Russian].

19 Mamay, I.I. (2003). Landshaftnyi statsionar v Meshchere [Landscape stationary in Meschera]. Geografiia i prirodnye resursy - Geography and natural resources, 2; 63-66 [in Russian].

20 Mamay, I.I. (2007). O vklade zimnikh sostoianii prirodnykh territorialnykh kompleksov v ikh razvitie [On the contribution of winter states of natural territorial complexes to their development]. Izvestiia Russkogo geograficheskogo obshchestva - Proceedings of Russian Geographical Society, 139, 4, 18-29 [in Russian].

21 Mamay, I.I. (2008). O vklade vesennikh sostoianii prirodnykh territorialnykh kompleksov v ikh razvitie [On the contribution of spring states of natural territorial complexes to their development]. Izvestiia Russkogo geograficheskogo obshchestva - Proceedings of the Russian Geographical Society, 140, 9-20 [in Russian].

22 Mamay, I.I. (2010). Zakonomernosti razvitiia prirodnykh territorialnykh kompleksov v letnie sezony (na primere YugoVostochnoi Meshchery) [Regularities in the development of natural territorial complexes in the summer seasons (on the example of the South-Eastern Meshchera)] Izvestiia Russkogo geograficheskogo obshchestva — Proceedings of the Russian Geographical Society, 142; 21-31 [in Russian].

23 Letopis prirody. Tom XXXI. 2014 god. [Nature records. Volume XXXI, 2014]. (2015). Karadag [in Russian].

24 Letopis prirody. Tom XXXII. 2015 god. [Nature records. Volume XXXII, 2015]. (2016). Karadag [in Russian].

25 Letopis prirody. Tom XXXIII. 2016 god. [Nature records. Volume XXXIII, 2016]. (2017). Karadag [in Russian].

26 Letopis prirody. Tom XXXIV. 2017 god. [Nature records. Volume XXXIV, 2017]. (2018). Karadag [in Russian].

27 Letopis prirody. Tom XXXV. 2018 god. [Nature records. Volume XXXV, 2018]. (2019). Karadag [in Russian].

28 Letopis prirody. Tom XXXVI. 2019 god. [Nature records. Volume XXXVI, 2019]. (2020). Karadag [in Russian].

29 Kostenko, N.S., Kukushkin, O.V., \& Zuev, A.V. (2011). Klimat [Climate]. Karadag zapovednyi: nauchno-populiarnye ocherki - Karadag Reserved: Popular Science Essays. Simferopol: N. Orianda [in Russian]. 